\section{EREM 77/4}

Journal of Environmental Research Engineering and Management

Vol. 77 / No. 4 / 2021

pp. 6-18

DOI 10.5755/j01.erem.77.4.28096

\section{Sustainability of Rice Business in Flood-Prone Areas}

Received 2020/12

Accepted after revision 2021/10

\title{
Sustainability of Rice Business in Flood-Prone Areas
}

\author{
Muzakar Isa*, M. Farid Wajdi, Mabruroh, Siti Fatimah Nur Hayati \\ Department of Management, Economics and Business Faculty, Universitas Muhammadiyah Surakarta, \\ Indonesia 57102
}

\author{
Nitty Hirawaty Kamarulzaman \\ 2Department of Agribusiness and Bioresource Economics, Faculty of Agriculture, Universiti Putra Malaysia, \\ 43400 UPM Serdang, Malaysia
}

\section{*Corresponding author: muzakar.isa@ums.ac.id}

Rice issues are strategically important given that food sovereignty is one of the government's strategic plans. The supply chain of rice is a complex system involving many interacting stakeholders. This study aims to analyse the rice supply chain in flood-prone areas, the level of rice business vulnerability to flooding, and the institutional competitiveness in the rice supply chain to improve food security. This study applied a mixed-method approach. The population of this research was business operators in the rice supply chain in the flood-prone areas of Klaten Regency, Indonesia. This study utilized primary data, which were collected using the method of direct interviews with business actors, supported by a list of questions and focus group discussions. The analytical tools used in this study were supply chain analysis, business vulnerability index, and stakeholder analysis. The results show that the rice supply chain consisted of farmers and rice fellers, collectors, rice mills, wholesalers, retailers and, finally, consumers. The vulnerability of companies in the rice supply chain was in the category of moderate. Stakeholders in the rice supply chain had diverse objectives, where the two most substantial goals were building reputation and earning income. Rice mill, Department of Agriculture, Food Security and Fisheries, and community are the main stakeholders in realizing food security because they have high interests and influence. The implication is that these three stakeholders must be the main actors in the development of regional food security.

Keywords: Stakeholders analysis, supply chain, business vulnerability. 


\section{Introduction}

Food security is one of the national development priorities in the Indonesian Government Work Plan (Yuniarti and Purwaningsih, 2017; Silalahi, 2019). Food security is the ability of an individual or household to have physical and economic access to sufficient, safe, and nutritious food to meet the needs and food preference for doing an active and healthy life (Pradana et al., 2019; Ugochukwu, and Baidoo, 2019). The Government of Indonesia continues to improve food security by three pillars, which are availability, accessibility, and utilization (Abdullah et al., 2019). Based on the 2018 Global Food Security Index (GFSI), Indonesia's food security in 2018 was in the $65^{\text {th }}$ position of 113 countries (The Economist Intelligence Unit, 2018). This position has improved in recent years. The survey results of the Indonesian Food Security Agency in 2019 ranked Klaten Regency $77^{\text {th }}$ of all districts in Indonesia, and the last rank in the former residency area of Surakarta (Badan Ketahanan Pangan Indonesia, 2019). Abdullah et al. (2019) have recognized three significant factors that affect food security, i.e., availability of food, accessibility of food, and utilization of food. The availability of food means ample food available through production. Accessibility of food means a reduction in poverty, since merely the availability is not enough, and the poor household should have the ability to purchase it. The utilization of food means food having all the required nutrients in it. Other researchers like Yuniarti and Purwaningsih (2017), Sati and Vangchhia (2017), and Pradana et al. (2019) added aspects of stability in the aspect of food security; thus, there are four aspects of food security, namely availability, access, utilization, and stability.

The main product of food security is rice, which is the staple food of the majority of the population. In the last five years, in 2014-2018, rice production in Klaten District experienced fluctuations. Rice production in 2014 amounted to 359,474 tons; in 2015 , it amounted to 406,434 tons; in 2016 , it amounted to 425,916 tons; in 2017, it amounted to 380,268 tons; and in 2018, it amounted to 390,038 tons (BPS Klaten, 2019). Natural disasters, especially floods, influenced one of the changes in production. Floods damage agricultural land and rice crops, so the amount of harvest has decreased. It is supported by research by Isa and Mangifera (2019), who explain that Klaten Regency has an area of vulnerability to moderate flooding. The level of vulnerability of the region has a strong correlation with the amount of rice production (Chen and Villori, 2019). When the area is not vulnerable to flooding, the land and rice plants are safe from flood disruption so that rice production is high. The availability of rice must be maintained as the primary input for milling in producing rice. Rice must be available in increasing numbers each year to compensate for the growing population demand in line with population growth.

Klaten Regency as an area most prone to non-coastal flooding is interesting to study if it is related to food security consisting of aspects of accessibility, utilization of rice as a staple food of the community, as well as price stabilization (Yuniarti and Purwaningsih, 2017; Sati and Vangchhia, 2017). Klaten is a district with a moderate level of vulnerability (Isa dan Mangifera, 2019), where the sensitivity variable is the highest forming aspect of regional vulnerability. Sensitivity is an aspect of vulnerability that explains the level of individual conditions in society, and their environment for the existence of flooding in an area (Luers, 2005). This aspect explains the socio-economic community, which consists of the level of income, health, access to clean water, and migration. This aspect influences people's access to and utilization of food.

Klaten Regency is a non-coastal area in Central Java Province, Indonesia, which experiences the most floods (Isa et al., 2019). Many businesses in the rice supply chain are in this region, so they have a high level of risk of damage and loss when floods occur (Thun et al., 2011; Belas et al. 2014; Pangestuti and Setiadi, 2019). Business actors have an essential role in maintaining food security, especially in the production and distribution of rice (Tiwu et al., 2019). They will survive if they can anticipate and adapt to the external business environment, one of which is flooding (Verbano and Venturini, 2013). With this, businesses in the region will survive if they can adapt or stage with a low level of vulnerability to flooding areas and 
are also able to keep their vulnerability levels low (Belas et al., 2014).

Business vulnerability is a condition where companies cannot avoid and face risks from the external environment such as disasters, policy changes, and technological developments (Wagner and Neshat, 2012; Verbano and Venturini, 2013). Business vulnerability to flooding is a negative factor that reduces and destroys the competitiveness of companies in the rice supply chain (Arend and Wisner, 2005). Companies that do not have a lot of resources, abilities and competencies to manage and control the risk of damage and losses are very vulnerable when there is a threat of flooding. Business vulnerability is an important aspect to study because it determines the competitiveness of companies in the rice supply chain in order to achieve food security (Vaaland and Heide, 2007; Wagner and Neshat, 2012). There are four types of business vulnerability, namely, financial vulnerability, labor, suppliers, and customers (Verbano and Venturini, 2013; Thapa et al., 2018).

The level of business vulnerability in the rice supply chain affects the level of food security (Wagner and Neshat, 2012), where farmers act as rice producers, while rice harvesters and collectors act as intermediaries between farmers and rice mills. Rice millers have a role in grinding rice, while traders play a role as intermediaries from rice millers to consumers, both intermediate and final consumers (Silalahi et al., 2019). In addition to business actors in the rice supply chain, other stakeholders support the level of food security, namely universities; Regional Planning, Research and Development Agency; Department of Agriculture, Food Security, and Fisheries; Department of Trade; cooperatives, small and medium enterprises, and the community. The stakeholders are partially very potential to realize food security, but so far, there has been no coordination and cooperation in realizing regional food security. With this, it is necessary to carry out a comprehensive and integrated study of the analysis of rice supply chains in flood-prone areas, analysis of the level of rice business vulnerability to flooding, and analysis of objectives and convergence of stakeholders in the rice supply chain to improve food security.

\section{Research Methods}

This study applied a mixed-method approach (Fauzi, 2019) that extended to identify the rice supply chain analysis in flood-prone areas, analyze the level of vulnerability of business units to flood threats and to analyze stakeholders' objectives and competitiveness of business actors in rice supply chains in flood-prone areas of Klaten Regency, Central Java, Indonesia.

This research was conducted in Klaten Regency, Central Java Province, Indonesia. Klaten is one of the districts in the Central Java Province of Indonesia, located between $7^{\circ} 32^{\prime} 19^{\prime \prime}$ to $7^{\circ} 41^{\prime} 8^{\prime} 33^{\prime \prime}$ south latitude and $110^{\circ} 26^{\prime} 14^{\prime \prime}$ to $110^{\circ} 47^{\prime} 51^{\prime \prime}$ east longitude. Administratively, Klaten Regency is divided into 26 sub-districts, 391 villages, and 10 village offices. The area of Klaten Regency is divided into 3 plains, namely Merapi Slope Plain, Kapur Mountain Plains, and Lowlands. The longitudinal lowlands in the middle cover the entire district area in Klaten Regency, except for a small portion of the area, which is the slopes of Mount Merapi and Mount Kapur (BPS, 2019). Klaten Regency is a region of high-quality rice and rice producers and is also the most flood-prone region in Central Java Province, Indonesia, for the category of non-coastal areas (Isa et al., 2019).

The population of this study was companies in the rice supply chain located in flood-prone areas in Klaten Regency, Central Java Province, Indonesia. This study used a purposive sampling technique, namely business actors who have experienced flooding three times. This study employed a survey method directly to businesses in flood-prone areas. This study utilized primary data, namely, data about the area of vulnerability and data about the level of vulnerability of the company. Data collection applied the method of direct interviews with company leaders which were supported by several questionnaires or questionnaires and focus group discussions about aspects of vulnerability to flooding. The analytical tools used in this study were descriptive analysis, business vulnerability index, and stakeholder analysis.

Descriptive analysis was employed to describe the rice supply chain in flood-prone areas. This analysis was conducted by snowballing the business actors 
in the rice supply chain until it could be comprehensively described the rice supply chain. The company's vulnerability index for flooding was done through a compilation of all aspects of the vulnerability aspects, consisting of variables of supplier vulnerability, labor vulnerability, capital vulnerability, and consumer vulnerability. The weighting of each variable due to consideration of the effect of each aspect was carried out in shaping the aspect of vulnerability. The greater the influence of these aspects, the higher the weight given. Weighting was obtained through FGD with stakeholders related to flood risk reduction at the study site. Furthermore, the determination of the vulnerability index value was established by the multiplication between the total scores of all indicators and the variable weights of supplier vulnerability, labor vulnerability, capital vulnerability, and consumer vulnerability (Weis et al., 2016). The company vulnerability index value for flooding was determined by the following formula (Isa et al., 2018):

$$
I K U=\sum_{i=1}^{4}\left(W_{1} x X_{1}\right)+\left(W_{2} x X_{2}\right)+\left(W_{3} x X_{3}\right)+\left(W_{4} X X_{4}\right)
$$

Where: $I K U$ = business vulnerability index for flooding; $W_{1}=$ the weight of supplier vulnerability; $X_{1}=$ supplier vulnerability score; $W_{2}=$ the weight of labor vulnerability; $X_{2}=$ labor vulnerability score; $W_{3}=$ the weight of capital vulnerability; $X_{3}=$ capital vulnerability score; $W_{4}=$ the weight of customer vulnerability; $X_{4}=$ customer vulnerability score.

In stakeholder's analysis, the Matrix of Alliances and Conflicts: Tactics, Objectives, and Recommendations (MACTOR) was used to analyze the influences and interests of stakeholders, consisting of raw material suppliers, producers, wholesalers, and consumers (Godet, 1991). The stakeholder's analysis is extensive because it can be used for up to 20 related purposes, and yet it is accessible and straightforward (Godet, 1991; Rees and MacDonell, 2017). MACTOR includes several stages of matrix preparation, namely: (1) determination of critical variables and relevant players; (2) preparation of table of stakeholder; (3) preparation of strategic issues and objectives; (4) determination of players and strategic objectives in the matrix; (5) calculation of convergence and divergence matrices as performed in three stages; (6) calculation of the direct and indirect relationship of power matrix; (7) calculation of the position matrix value; and (8) analysis of strategic recommendations of each player (Godet, 1991; Reed et al., 2009).

\section{Results and Discussion}

\section{Rice supply chain}

Rice is the primary food type of Indonesian people and also the main product in supporting the level of food security (Bidarti et al., 2019; Silalahi et al., 2019). The availability, access, utilization, and stabilization of rice prices are essential for realizing food security so that the performance of businesses in the rice supply chain plays a vital role in realizing the level of food security (Vlajic, 2012; Chen et al., 2019). Rice supply chain analysis is fundamental to identify, map, and maintain the sustainability of the region's food security (Gao, 2015).

Businesses in the rice supply chain have different suppliers and consumers (Aprillya et al., 2019). Some business units have suppliers and consumers in a wide area, and some other business units have suppliers and consumers in a narrow area. Business units in the rice supply chain in flood-prone areas are illustrated in Fig. 1.

Fig. 1 explains that every business in the rice supply chain in a flood-prone area has suppliers inside or outside a flood-prone area. Likewise, consumers may be inside, partially inside, or outside the flood-affected area. Conversely, businesses outside flood-prone areas can also be affected by the disruption of suppliers and consumers. Businesses outside flood-prone areas may be more severely affected than businesses in flood-prone areas.

Among the business actors involved in the rice and rice supply chain are (1) farmers. The rice supply chain is originated from farmers as rice producers. Farmers have a vital role as rice producers, where the quality and quantity of supply depend on them. Farmers plant rice on their land or leased land. The harvest is sold to the fellers or rice collectors. Rice sales are 
Fig. 1. Business relationships in the rice supply chain in flood prone areas

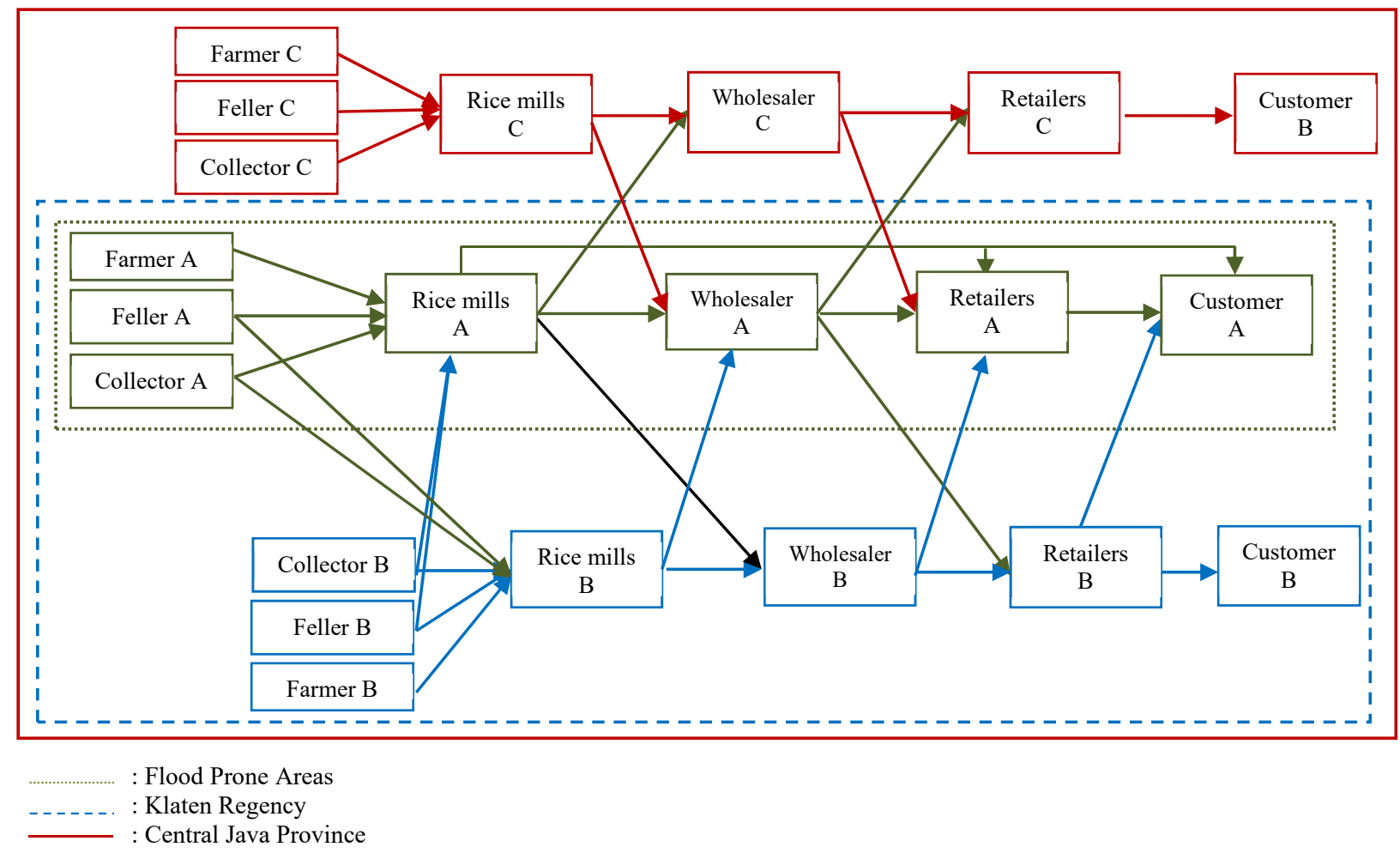

carried out in two ways, namely selling rice that is still in the fields and not yet harvested to the loggers and selling the harvested rice and drying it to collectors. (2) Rice fellers are a member of the supply chain that acts as a liaison between farmers and rice millers. Fellers collect rice from farmers, and then rice is sold to rice mills and/or collectors. Rice is usually bought directly at the harvest location, namely rice fields. Yields purchased directly are sold to rice mills without any drying. (3) Collectors buy rice after it is harvested, both from fellers and farmers, and from other traders. Payments are made in cash after rice is weighed and ready to be transported. Collectors operate at the village level and can also be between villages. They are grouped into two categories, namely millers' agents and independent collectors. Millers' agents are traders who are given capital by rice mills to buy rice, both by slash and by buying from farmers and loggers. Meanwhile, independent traders are traders who use their business capital but have a rice mill factory subscription. Collectors generally sell rice to rice mills. (4) Rice milling. This supply chain holds rice from farmers, fellers, and collectors to be ground into rice. There are two types of rice purchased, namely wet rice and dry rice, ready for milling. Rice milling business activities consist of rice drying, rice milling, and rice packaging. Value-added activities are mostly concentrated in the rice milling business group (Sasmita and Apriyanti, 2019). Distribution activities from milling to rice traders depend on the agreement between the two. There are times when shipments are carried out by mills reaching rice traders, and traders can also take rice from the mill. Finally, (5) rice traders are grouped into two types, namely wholesalers and retailers. Wholesalers have the activity of adding value through grading and packaging. Wholesalers generally pack with certain trademarks, and rice is marketed to supermarkets, minimarkets, restaurants/food stalls, and rice retailers. Small traders or retailers get rice from rice grinders or large traders/wholesalers. The rice is then sold to consumers. 
Food security is influenced by the performance of each business unit in the rice supply chain, which includes aspects of availability, access, and utilization (Yang et al., 2018; Thapa et al., 2018). The performance of companies in flood-prone areas is influenced by their understanding of flooding and the level of business vulnerability (Isa et al., 2015). Company performance in the rice supply chain will be effective if every business actor has a level of understanding to reduce the level of good business vulnerability (Yang et al., 2018).

\section{Business vulnerability due to flooding}

Food security will be achieved if businesses in the rice supply chain have low levels of business vulnerability. Business vulnerability is a business condition that cannot avoid and face risks from the external environment, such as disasters, policy changes, and technological developments (Luets, 2005; Isa et al., 2015; Isa, 2016). Business vulnerability to flooding is one type of vulnerability faced by companies because, in the short term, it has a negative impact on business performance (Verbano and Venturini, 2013).

Business vulnerability to flooding can be explained through the business vulnerability index. This vulnerability index is determined by the total score of all indicators of the variables of supplier vulnerability, labor vulnerability, capital vulnerability, and consumer vulnerability. The calculation results explain that the business vulnerability index for flooding was 0.52 , which means that businesses in the rice supply chain are in the moderate vulnerability category. Wholesalers were the most vulnerable business groups (0.53), followed by retail traders (0.52), and farmers (0.52), and the last was rice millers (0.51).

Table 1. Business vulnerability index in flood prone areas

\begin{tabular}{|c|c|c|c|c|c|}
\hline Vulnerability index & Farmers & Rice millers & Wholesaler & Retailers & INDEX \\
\hline Supplier vulnerability & 0.38 & 0.44 & 0.56 & 0.30 & 0.42 \\
\hline Capital vulnerability & 0.52 & 0.47 & 0.51 & 0.51 & 0.50 \\
\hline Labor vulnerability & 0.72 & 0.53 & 0.64 & 0.52 & 0.60 \\
\hline Consumer vulnerability & 0.44 & 0.60 & 0.39 & 0.73 & 0.54 \\
\hline INDEX & 0.52 & 0.51 & 0.53 & 0.52 & 0.52 \\
\hline
\end{tabular}

Rice wholesalers are businesses in the rice supply chain that are most vulnerable to flooding. They are most vulnerable to labor aspects. During and after the flood, many workers choose to focus on their personal needs so that many businesses find it difficult to find workers. In addition to the labor aspect, rice wholesalers are also vulnerable to rice suppliers, namely rice millers. At the time of the flood, rice millers experience a shortage of supply, which also impacts rice peddlers. Capital and consumer aspects are not the main problems because they generally already have capital reserves and it is not difficult to find additional capital. From the consumer side, because the rice stock is small, the consumer is not a problem. Farming is very vulnerable in the aspect of labor, where aspects of labor were at a high level of vulnerability (0.72). Labor is the most critical component in farming, where labor costs are the highest component in the production cost structure (Silvira et al., 2014; Azhiim et al., 2017). During floods, many workers focus on their individual needs and do not want to work as farm laborers. Labor vulnerability is the highest, followed by capital, consumer, and supplier vulnerabilities.

Rice milling business is most vulnerable to the consumer aspect. Rice mills get rice from around and outside the region, as well as for consumers. For rice mills where the majority of consumers are the people living near businesses, consumers do not focus on purchasing rice during floods. Consumer vulnerability is the highest, followed by labor, capital, and supplier vulnerabilities. 
Rice retailers or stores are the newest business units in the rice supply chain before consumers. They are most vulnerable to consumers where consumers are at a high level of vulnerability (0.73). When floods occur, rice purchases decline; it could be so because the consumers' primary focus is on health rather than rice purchases. Consumer vulnerability is the highest cost, then followed by consumer pressure, capital, and, finally, suppliers.

Based on the types of aspects forming business vulnerability, labor is the most vulnerable type. The next most vulnerable aspects, respectively, are consumers, capital, and suppliers. All types of vulnerability builders are in the medium vulnerability category. Labor is an essential aspect of the performance of companies, especially companies in the rice and rice supply chain (Silvira et al., 2014; Azhiim et al., 2017). A large number of new big companies for textile products also have an impact on the interest of workers to work in the SME sector.

\section{Objectives and convergence of stakeholders in the rice supply chain}

Identification and discussion of stakeholder objectives and convergence in the rice supply chain used stakeholder analysis through the MACTOR method. This analysis was used to identify and understand stakeholder interests, desires, and perceptions of strengthening food security in flood-prone areas. This analysis identifies the role and views of the objectives of strengthening food security and maps the convergence between the stakeholders involved (Isa et al., 2019; Fauzi, 2019). A total of 13 types of stakeholders, namely academics, bureaucracy, community leaders, and business actors, were involved in this stakeholder analysis. Each stakeholder was asked for their opinions and perceptions regarding their daily activities related to food security. As shown in Fig. 2, the highest score was obtained to find reputation and income. With this, it is understood that many of the objectives of these stakeholder activities are looking

Fig. 2. Business relationships in the rice supply chain in flood prone areas

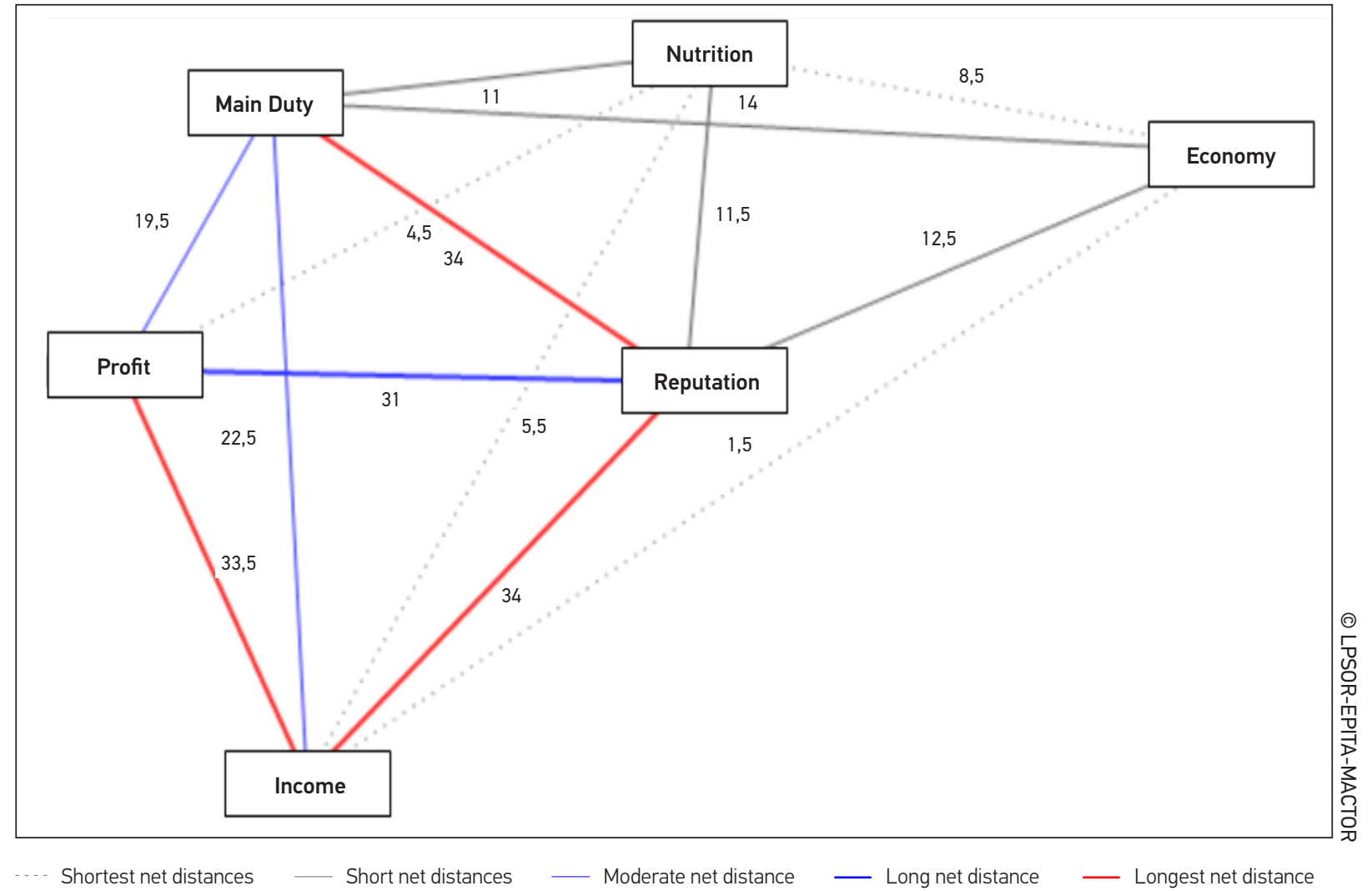


for reputation and also income. Not many stakeholders consider three main aspects of food security in their activities, namely the availability of rice, access to rice, and the utilization of rice into healthy and nutritious food. It is supported by the attitude of stakeholders who put aspects of the local economy and nutrition as the lowest objective.

The situation in Fig. 2 shows the strength of stakeholders towards several alternative objectives (Fauzi, 2019). As seen in Fig. 2, there are six objectives, namely reputation, income, profit, primary duty, nutrition, and local economy. Of the six goals, the most substantial goals are reputation and income. In addition to these two goals, there are other relatively strong goals, namely profit and primary duty, while the weakest goals are nutrition and local income.

Fig. 3 maps the position of each stakeholder viewed from two main aspects, namely influence and dependence. The results of the stakeholder map them into four quadrants, namely quadrant 1: actors, quadrant 2: players, quadrant 3: subjects, and quadrant 4: bystanders (Isa et al., 2019; Fauzi, 2019). Actors are stakeholders who have low interest but have a strong influence on strengthening food security. This quadrant is occupied by the Regional Planning, Research, and Development Agency (Bappeda), the Department of Trade, Cooperatives, and SMEs (DPK and UKM), rice wholesalers, and eice retailers. Stakeholders in this group have interests in planning, management, direction, guidance, and evaluation at the local government level. This group also provides and sells rice to intermediate and end consumers. This group has a significant influence on regional economic planning, controlling prices, and selling rice.

Players are the most active stakeholders in realizing food security in this region because they have high interests and influence. This quadrant is occupied by a rice mill, Department of Agriculture, Food Security,

Fig. 3. Map of influence and interdependence between stakeholders

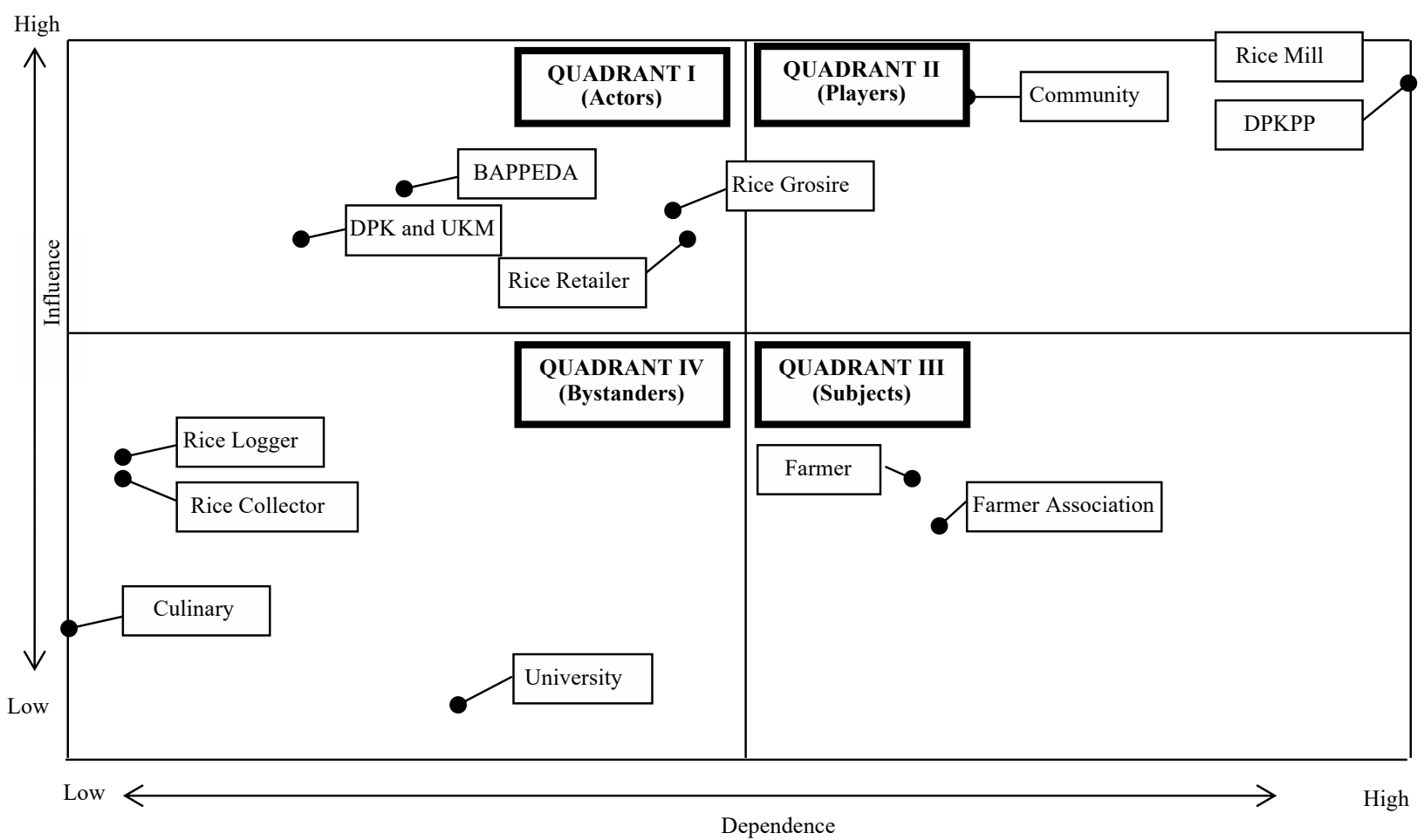

BPBD: Badan Penanggulangan Bencana Daerah (Regional Planning, Research, and Development Agency); DPKPP: Dinas Pertanian, Ketahanan Pangan Dan Perikanan (Department of Agriculture, Food Security, and Fisheries); DPK and UKM: Dinas Perdagangan, Koperasi dan Usaha Kecil Menengah (Department of Trade, Cooperatives, and SMEs). 
and Fisheries (DPKPP), and community. Stakeholders in this quadrant provide various resources in realizing food security, either for human resources, information, facilities, and products. The main focus of the program to strengthen food security is to ensure the availability, access, and use of primary products, namely rice, as a staple food source for the community. The influence of each stakeholder in the players' quadrant is high. They have the authority to maintain the availability of rice, the ability to buy rice, and utilize rice in this region. Each party carries out activities that support food security, such as conducting rice production, conducting counseling, and doing socialization to the community, as well as providing information, training, and providing facilities to support food security.

Subjects have great importance, but their effect is small in strengthening food security. This quadrant is occupied by farmers and the farmer association. Stakeholders in the subject's quadrant having the highest importance are rice producers. When viewed from the involvement of stakeholders, they do not have involvement in planning, organizing, and controlling in realizing food security. The level of group dependency in this quadrant is related to rice production as their source of income. The influence of stakeholders in the quadrants of subjects is low. The groups in this quadrant do not have the authority to control food security, and they only play a role in the implementation of rules and policies related to rice production. They also cannot interact either in holding forums, cooperation, or changing the direction of strengthening food security.

Bystanders are stakeholders with low interests and influence in realizing food security. This quadrant is occupied by rice collectors, rise loggers, food SMEs (culinary SMEs), and the university. Judging from the involvement, benefits obtained, and the level of dependence on food security, stakeholders in this quadrant have very low values. This group only carries out its duties as an intermediary between farmers and rice mills, and also as a motivator or innovator. The stakeholders in this quadrant have a very low value and do not contribute to the management of food security in Klaten Regency.

Fig. 4. Actor relationships map in realizing food security

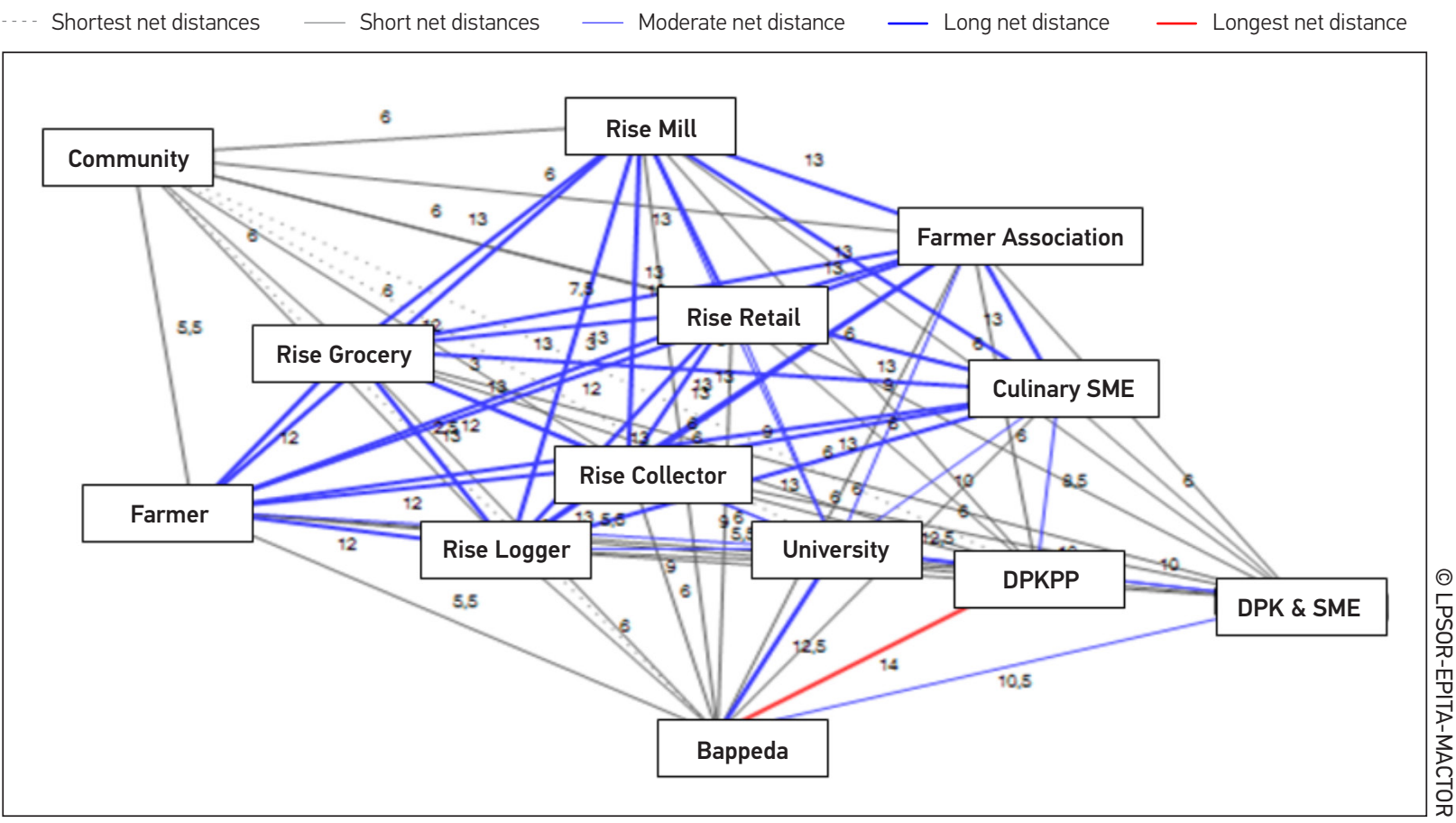

BPBD: Badan Penanggulangan Bencana Daerah (Regional Planning, Research, and Development Agency); DPKPP: Dinas Pertanian, Ketahanan Pangan Dan Perikanan (Department of Agriculture, Food Security, and Fisheries); DPK and UKM: Dinas Perdagangan, Koperasi dan Usaha Kecil Menengah (Department of Trade, Cooperatives, and SMEs). 
Fig. 4 explains the proximity of stakeholders in realizing food security (Isa et al., 2019; Fauzi, 2019). From the figure above, net distances are mapped between stakeholders in realizing food security in general, which has close proximity in the sense that stakeholders are involved in mutual support; these stakeholders are BAPPEDA and DPKPP. The power of convergence as the primary stakeholder is possible because of the similarity of perception and interest. BAPPEDA is an agency that plays the role of a planner and coordinator of regional government development programs, in this case, regional food security. The DPKPP Office is a professional implementing agency related to food security in the region.

Fig. 5. Convergence actors map in realizing food security

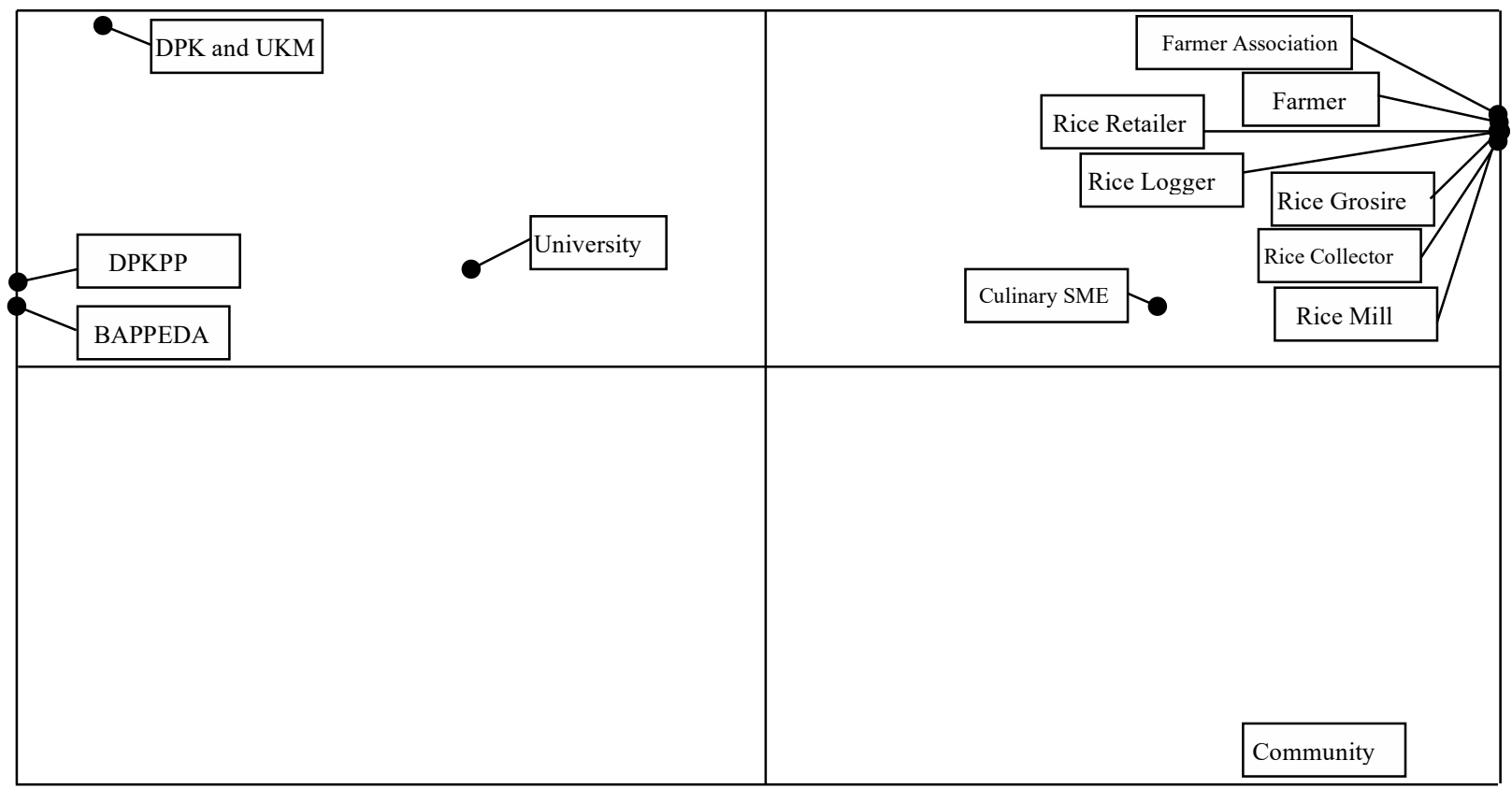

BPBD: Badan Penanggulangan Bencana Daerah (Regional Planning, Research, and Development Agency); DPKPP: Dinas Pertanian, Ketahanan Pangan Dan Perikanan (Department of Agriculture, Food Security, and Fisheries); DPK and UKM: Dinas Perdagangnan, Koperasi dan Usaha Kecil Menengah (Department of Trade, Cooperatives, and SMEs).

Fig. 5 presents a mapping of convergence among the stakeholders involved. The convergence in question is the tendency among stakeholders to jointly agree on the various objectives of the actors in programs and activities to strengthen food security (Isa et al., 2019; Fauzi, 2019). The convergence group occurs at right angles, namely between agencies related to strengthening food security, including farmers, farmer groups, rice fellers, rice collectors, rice mills, wholesalers, retailers, and food businesses. The position of BAPPEDA, DPKPP, Trade Agencies, Cooperatives, and SMEs, and universities are in a separate group because the position of these stakeholders is convergent weak. Besides, the position of society is in a position of weak convergence. It might be due to the concern of the public as consumers of the product. Stakeholders must work in synergy and together to improve food security (Dewi and Yustikaningrum, 2018). Stakeholders who are in the actors' group must act as good planners and mobilizers in realizing food security, and stakeholders in the player group must be optimized as crucial people in strengthening food security.

\section{Conclusion}

This study aims to analyze the rice supply chain in flood-prone areas, analyze the level of rice business vulnerability to flooding, and analyze the objectives and convergence of stakeholders in the rice supply chain to improve food security. 
The rice supply chain in flood-prone areas of Klaten Regency consists of farmers and rice fellers, collectors, rice mills, wholesalers, small traders/retailers, and finally, consumers. The vulnerability of companies in the rice supply chain was in the category of moderate vulnerability. Based on the types of subjects, large traders/ wholesalers were the most vulnerable business actors, followed by retailers and farmers, and, finally, the rice millers. Based on the types of aspects that make up corporate vulnerability, the most vulnerable types were labor, followed by consumers, capital, and suppliers. All types of forming this vulnerability were in the medium vulnerability category. Companies in the rice supply chain are essential elements to maintain food security, both in availability, access, utilization, and stability. Rice companies in the rice supply chain must be maintained for food security sustainability. Flooding as a threat from outside the company must be appropriately managed by reducing the level of vulnerability of the company so that the risk of flooding becomes lower or the resilience of the company increases.

Key persons in food security in this region were 13 types of stakeholders, ranging from academics, bureaucracy, community leaders to business actors, and they were involved in this stakeholder analysis. They had six goals, namely building a reputation, looking for income, looking for profit, implementing primary duties, supporting food quality and nutrition, and improving the local economy. Of the six goals, the most substantial goals were reputation and income, while the weakest goals were nutrition and local income.

The results of the stakeholders map them into four quadrants, namely quadrant 1 (actors), quadrant 2 (players), quadrant 3 (subjects), and quadrant 4 (bystanders). Actors are stakeholders who have low

\section{References}

Abdullah, D, Z., Tariq S., Sajjad, A., Waqar, A., Izhar U., Aasir I. (2019) Factors affecting household food security in rural northern hinterland of Pakistan. Journal of the Saudi Society of Agricultural Sciences 18 (2019) 201-210. https://doi.org/10.1016/j. jssas.2017.05.003

Aprillya, M. R., Suryani, E. Dzulkarnain, A. (2019) System Dynamics Simulation Model to Increase Paddy Production for Food Security. Journal of Information Systems Engineer- interests but have a high influence on strengthening food security. Players are the most active stakeholders in realizing food security in this region because they have high interests and influence. Subjects have great importance, but their effect is small in strengthening food security. Bystanders are stakeholders with low interests and influence in realizing food security.

Stakeholders who had a close interest were BAPPEDA and DPKPP. BAPEDDA is an agency that plays a role as a government program planner; in this case, regional food security. The DPKPP Office is a professional implementing agency related to food security in the region. Furthermore, stakeholders are mapped into three groups, based on the tendency among stakeholders to jointly agree on various stakeholder goals in programs and activities to strengthen food security. Group 1 consists of farmers, farmer groups, rice fellers, rice collectors, rice mills, wholesalers, retailers, and food businesses. Group 2 consists BAPPEDA, DPKPP, Trade Agencies, Cooperatives and SMEs, and Universities are in separate groups because their position is convergently weak; and Group 3 is the community. With this, it is necessary to propose an institutional model that involves groups of actors and players in one group because they are very instrumental in realizing food security in the area.

\section{Acknowledgment}

We wish to thank the Institute for Research and Community Service (Lembaga Penelitian dan Pengabdian Masyarakat) at Universitas Muhammadiyah Surakarta for providing financial support to this study. In addition, we would also like to extend our gratitude to anonymous reviewers for their helpful comments and suggestions.

ing and Business Intelligence. Vol.5, No.1, 67-75. https://doi. org/10.20473/jisebi.5.1.67-75

Arend, R. J., and Wisner, J. D. (2005) Small Business and Supply chain management: is there a fit? Journal of Business Venturing, 20, 403-436. https://doi.org/10.1016/j.jbusvent.2003.11.003

Azhiim, A., Ekowati, T., and Setiadi, A. (2017) Analisis Optimasi Cabang Usahatani Padi Dan Kedelai Di Kecamatan Purwodadi Kabupaten Grobogan (The Analysis of Optimization Branch of 
Farming of Rice and Soybean In Distric of Purwodadi Grobogan Regency), Prosiding "Penyiapan Generasi Muda Pertanian Perdesaan Menuju Indonesia Sebagai Lumbung Pangan Dunia" Seminar Nasional, Malang 10 April 2017

Belas, J.; Machacek, J.; Bartos, P.; Hlawiczka, R.; Hudakova, M. (2014) Business Risks and the Level of Entrepreneurial Optimism among SME in the Czech and Slovak Republic. JOC 2014, 6, 30-41. https://doi.org/10.7441/joc.2014.02.03

Bidarti, A, Darwanto, D. H., Hartono, S., Jamhari (2019) Supplier Structure and Performance Evaluation of Supplier Network Phase Rice Supply Chain Management in South Sumatra. AGRARIS: Journal of Agribusiness and Rural Develpoment Research, Vol. 5 No. 1. https://doi.org/10.18196/agr.5171

Badan Pusat Statistik (Klaten Regency Central Statistics Agency), 2019, Klaten Dalam Angka Tahun (Klaten Regency in Figures), BPS, Klaten.

Chen, B. and Villori, N.B. (2019) Climate shocks, food price stability and international trade: evidence from 76 maize markets in 27 net-importing countries. Environmental Research Letters 14 014007. https://doi.org/10.1088/1748-9326/aaf07f

Dewi, G. D. P. and Yustikaningrum, R. V. (2018) Improving food security empowerment in Indonesia- Timor Leste border. IOP Conf. Series: Earth and Environmental Science 126 (2018) 012127. https://doi.org/10.1088/1755-1315/126/1/012127

Fauzi, A. (2019) Teknis Analisis Keberlanjutan (Sustainability Analysis Techniques), Gramedia Pustaka Utama; Jakarta

Gao, L. (2015) Long-Term Contracting: The Role of Private Information in Dynamic Supply Risk Management. Production and Operations Management. 24, 1570-1579. https://doi. org/10.1111/poms. 12347

Godet, M. (1991) 'Actors' move and strategies: The MACTOR method an air transport', Futures Journal 23, 605-622. https:// doi.org/10.1016/0016-3287(91)90082-D

Isa, M. (2016) Natural Disaster: Negative or Potisitive Impact to Economy Growth? The 3rd University Research Colloquium 2016, Kudus.

Isa, M. and Mangifera, L. (2019) Continuous flood risk reduction on MSMEs: Implementation of MACTOR program. Economic Journal of Emerging Markets, 11(1), 113-121. https://doi. org/10.20885/ejem.vol11.iss1.art12

Isa, M. Fauzi; Indah, A. Susilowati, I. (2019) Flood risk reduction in the northern coast of Central Java Province, Indonesia: An application of stakeholder's analysis. Jàmbá: Journal of Disaster Risk Studies 11(1), a660. https://doi.org/10.4102/jamba.v1 1i1.660

Isa, M., Sugiyanto, FX., Susilowati, I. (2018) Community resilience to floods in the coastal zone for disaster risk reduction, Jàmbá: Journal of Disaster Risk Studies, Vol 10, No 1. https:// doi.org/10.4102/jamba.v10i1.356
Isa, M., Sugiyanto, FX., Susilowati, I.. (2015) Adaptation and Mitigation Model for People to Restore Their Ecosystem from Flood in Semarang, Indonesia, Jurnal Ekonomi Pembangunan, Vol. 16, No 2, Tahun 2015. https://doi.org/10.23917/jep.v16i2.1461

Luers, A.L. (2005) "The Surface of Vulnerability: An Analytic Framework for Examining Environmental Change",Global Environmental Change 15: 214-223. https://doi.org/10.1016/j. gloenvcha.2005.04.003

Pangestuti, M. D., Setiadi, M., A. (2019) Analysis Supply Chain Distribution And Added Value Of Grain In Sub District Undaan Kudus Regency. Jurnal Ekonomi Pertanian dan Agribisnis (JEPA) Volume 3, Nomor 4 (2019): 671-680, ISSN: 2614-4670 (p), ISSN: 2598-8174 (e). https://doi.org/10.21776/ub.jepa.2019.003.04.2

Pradana, A., Pujiastuti, I., Paramita, P. P. (2019) Regionalization of Agricultural Based Leading Sectors and Food Security in Indonesia. IOP Conference Series: Earth and Environmental Science 338 (2019) 012015. https://doi.org/10.1088/17551315/338/1/012015

Reed, M.S., Graves, A., Dandy, N., Posthumus, H., Hubacek, K., Morris, J. et al. (2009) 'Who's in and why? A typology of stakeholder analysis methods for natural resource management', Journal of Environmental Management 90(5), 1933-1949. https://doi.org/10.1016/j.jenvman.2009.01.001

Rees, G.H. and MacDonell, S., 2017, 'Data gathering for actor analyses: A research note on the collection and aggregation of individual respondent data for MACTOR', Future Journal 9(1), 115-137. https://doi.org/10.24023/FutureJournal/2175-5825/2017.v9i1.256

Sasmita, Y. and Apriyanti, M. (2019) Income Analysis of "Cahaya Ummul" Rice Milling Business (Case Study) In Lakatan Village Galang Subdistrict of Toli-toli. Journal of Agroland 26 (1) : 7 - 13, 2019

Sati, V. P., and Vangchhia, L.(2017) Food Security Status in Rural Areas of Mizoram, Northeast India. J. Mt. Sci 4(4):795-805. https://doi.org/10.1007/s11629-016-4092-2

Silalahi, N.H., Yudha, R. O., Dwiyanti, E. I., Zulvianita, D., Feranti, S. N., and Yustiana, Y. (2019) Government policy statements related to rice problems in Indonesia: Review. 3BIO: Journal of Biological Science, Technology and Management Volume 1., Issue 1 (2019): 35 - 41. https://doi.org/10.5614/3bio.2019.1.1.6

Silvira, H. H., dan Fauzia, L (2014) Analisis Faktor-Faktor yang Mempengaruhi Produksi Padi Sawah (Analysis of Factors Affecting Rice Production), Jurnal Sosial Ekonomi Pertanian dan Agribisnis Universitas Sumatra Utara. 2 (4): 6-8.

Thapa, T. L., Bhattarai, Ch.; Khatri, B; Bhusal, K. (2018) Supply Chain Analysis of Rice Sub-Sector in Dang District, Nepal. International Journal of Applied Sciences and Biotechnology, Vol 6(4): 319-326. https://doi.org/10.3126/ijasbt.v6i4.22109 
The Economist Intelligence Unit (2018) 'The Global Food Security Index 2018: Measuring food security and the impact of resource risks', p. 56. Available at: http://foodsecurityindex.eiu.com/

Thun, J.H., Drüke, M. and Hoenig, D. (2011) "Managing uncertainty - an empirical analysis of supply chain risk management in small and medium-sized enterprises", International Journal of Production Research, Vol. 49(18), pp. 5511-5525. https://doi. org/10.1080/00207543.2011.563901

Tiwu, W. H.L., Sepang, J.L., Rate, P.V. (2019) Analysis of Rice suplly Chain Distribution Channels in Bolaang Mongondow (Case Study in North Mopugad Village Dumoga Sub-District). Jurnal EMBA Vol.7 No.1, 1031 - 1040

Ugochukwu, C. C. and Baidoo, P. (2019) Food Security: Peasant Farmers Role in the Sawla Tuna-Kalba District of Ghana. International Journal of Business and Social Science Vol. 10, No. 1, January 2019. https://doi.org/10.30845/ijbss.v10n1p4

Vaaland, T. I., and Heide, M. (2007) Can the SME survive the supply chainchallenges?SupplyChainManagement:AnInternational Journal, 12(1), 20-31. https://doi.org/10.1108/13598540710724374

Verbano, C. and Venturini, K. (2013) Managing Risks in SMEs: A Literature Review and Research Agenda. Journal of Technology Management and Innovation, 8 (3), 186-197. https://doi. org/10.4067/S0718-27242013000400017

Vlajic, J.V., Jack, G.A.J., van der Vorst, Haijema, R. (2012) A framework for designing robust food supply chains. Interna- tional Journal of Production Economics 137, 176-189. https:// doi.org/10.1016/j.ijpe.2011.11.026

Wagner, S., and Neshat, N. (2012). A comparison of supply chain vulnerability indices for different categories of firms. International Journal of Production Research, 50(11), 2877-2891. https://doi.org/10.1080/00207543.2011.561540

Weis, S.W., Agostini, V.N., Roth, L.M., Gilmer, B., Schill, S.R., Knowles, J.E., Blyther, R. (2016). Assessing Vulnerability: An Integrated Approach For Mapping Adaptive, Sensitivity, And Exposure. Climate Change 136:615-629. https://doi.org/10.1007/ s10584-016-1642-0

Yang, S.; Ishtiaq, M.; Anwar, M. (2018) Enterprise Risk Management Practices and Firm Performance, the Mediating Role of Competitive Advantage and the Moderating Role of Financial Literacy. J. Risk Finan. Manag. 11, 35. https://doi.org/10.3390/ jrfm11030035

Yuniarti, D. and Purwaningsih, Y. (2017) Household Food Security and Vulnerability: the Sustainable Livelihood Framework. JEJAK: Jurnal Ekonomi dan Kebijakan, 10(2), 223-241. https:// doi.org/10.15294/jejak.v10i2.11290

Badan Ketahanan Pangan (2019) Indeks Ketahanan Pangan Indonesia 2018. Badan Ketahanan Pangan Kementerian Pertanian. http://bkp.pertanian.go.id/storage/app/media/Pusat\%20 Ketersediaan/Bidang\%20Ketersediaan/Indeks\%20Ketahanan\%20Pangan\%202018.pdf 